Ann. Biol. anim. Bioch. Biophys., 1978, 18 (6), 1317-1324.

\title{
Sterols in various organs of adult female swine
}

\author{
par Jocelyne AIGUEPERSE, J. REMY, F. CHEVALLIER * \\ Laboratoire de Radiobiologie appliquée, Commissariat d̀ l'Energie Atomique, \\ Département de Profection, 78350 Jouy-en-josas, France \\ * Laboratoire de Physiologie de la Nutrition \\ Université Paris XI, Bât. 447, 91405 Orsay Cedex, France.
}

\begin{abstract}
Summary. Adult female swine were maintained at a constant weight of $70 \mathrm{~kg}$ by controlled feeding of a semi-purified diet. The concentrations of free and esterified sterols were determined in 17 tissues and organs. These concentrations were constant regardless of the diet period (3-32 weeks), except in the plasma, where a significant decrease was observed. The results are discussed and compared with those previously obtained with swine or rats. Gas chromatographic analyses showed that cholesterol was the major sterol, both in the free and esterified fractions. The percentage of cholesterol in total sterols reached 98 p. 100 or more in each organ or tissue except hair and bone marrow (free fraction only). In hair, desmostenol accounted for 35.5 p. 100 of the free sterols and 18.2 p. 100 of the esterified sterols. $\Delta^{7}$-cholesterol and methostenol, other cholesterol precursors, were detected in minute amounts in several organs. $\Delta^{7}$-cholestenol was present in bone marrow at a concentration of 3 p. 100 . Compared with rats, swine organs are poor in precursor sterols.
\end{abstract}

Concentrations of free and/or esterified cholesterol have been previously determined in some organs of swine, including plasma (Reiser ef al., 1959 ; Fausch ef al., 1968 ; Scott and Morrison, 1968 ; Stokke, 1974), liver (Reiser et al., 1959 ; Fausch et al., 1968 ; Stokke, 1974), aorta (Reiser et al., 1959 ; Scott and Morrison, 1968), coronary artery (Reiser et al., 1959), adipose tissue (Fausch et al., 1968), adrenals (Cmelik and Ley, 1975) and epidermis (Gray and Yardley, 1976). In addition, Kim ef al. (1974) studied 26 organs of 20 -week old swine, but only total cholesterol was measured. None of these studies included the sterolic « precursors » of cholesterol biosynthesis (fig. 1). As a prerequisite to metabolic research, it was felt that these data should be completed. In the present study concentrations of free and esterified sterols, on the one hand, and those of cholesterol and other sterols, on the other, were determined in 17 organs and tissues of adult female swine. For many experimental purposes the classic fattening of swine, observed when they are fed a common diet ad libitum, is not desirable. To avoid this fattening, adult swine have been maintained at constant weight by controlling the daily food intake. This study concerns adult female swine in a physiological equilibrium defined by their own strain and by the composition of the semi-purified diet fed to them. 


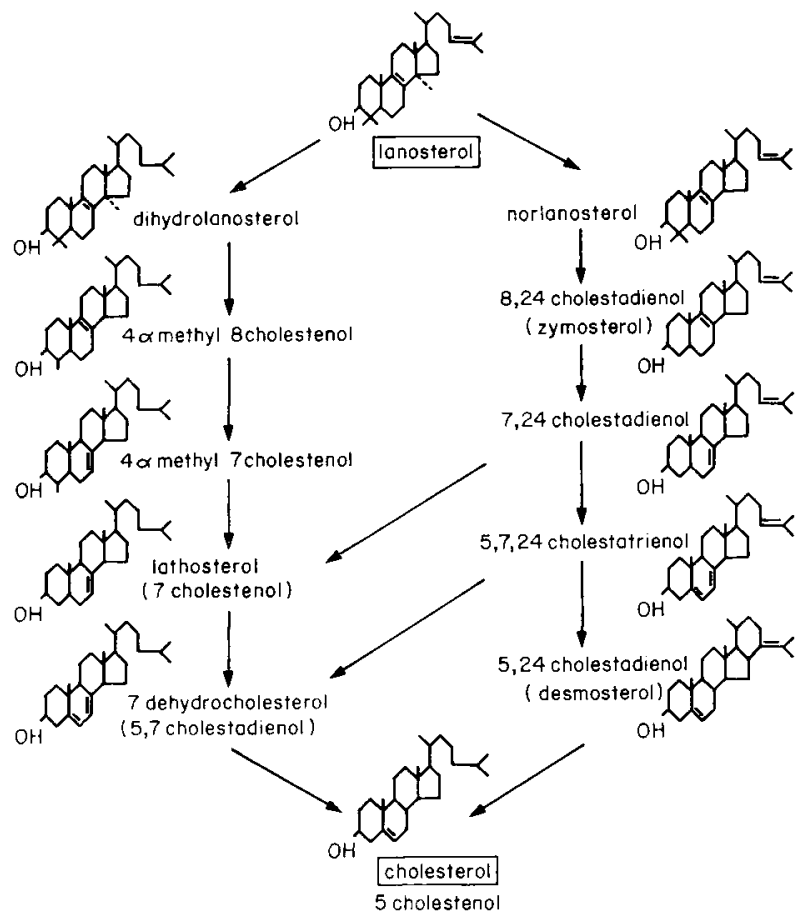

FIG. 1. - Sterolic precursors of cholesferol biosynthesis.

\section{Methods.}

After weaning, female swine of the Large White strain were fed a ground stock diet : 74 p. 100 barley, 4 p. 100 peanut oil cake, 4 p. 100 soybean oil cake, 3 p. 100 alfalfa meal, 4 p. 100 fish meal, 4 p. 100 yeast, 4 p. 100 vitamin mixture, 3 p. 100 mineral supplement. The vitamin composition and mineral supplement were those recommended in Nutrient Requirements of Swine (1968). The lipid concentration in this diet was 3.3 p. 100 , sterols 0.07 p. 100 ; cholesterol represented only 0.1 of this percentage, $\beta$-sitosterol 0.6 , campesterol 0.2 and other undetermined phytosterols 0.1 . This ground stock diet was adapted for moderate growth, and used for many experimental purposes. Its energy value was $3.91 \mathrm{Kcal} / \mathrm{g}$. Moreover, the diet was not furnished ad libitum to the swine, but was limited for a normal growth. Under these conditions, an 8-month old swine weighed approximately $70 \mathrm{~kg}$ instead of $110-120 \mathrm{~kg}$, as it would if fed, after weaning, a common diet ad libitum for fattening (Robinson, 1976). Water was always furnished ad libitum.

The criterion for beginning the experiment was animal weight $(70 \pm 2 \mathrm{~kg})$. At that time, twenty swine were fed a semi-purified diet : 34 p. 100 skim milk, 48 p. 100 starch, 4 p. 100 cellulose, 6 p. 100 lard, 2 p. 100 vitamin mixture and 6 p. 100 mineral salts. Vifamin composition and mineral salts were similar to the previously mentioned diet. Cholesterol concentration was 0.01 p. 100 and that of phytosterols was negligible $(<0.001$ p. 100). Energy value was $3.51 \mathrm{kcal} / \mathrm{g}$. 
The animals were fed twice daily at $8 \mathrm{a} . \mathrm{m}$. and $4.30 \mathrm{p}$. m. The daily quantity (between 0.8 and $1 \mathrm{~kg} /$ day) was slightly modified during the experiment in order to maintain a constant body weight. Two pigs were killed after 3,11 and 32 weeks, and the 14 others after 10 weeks ; their mean weight was $70.3 \pm 0.3 \mathrm{~kg}$ at the beginning and $70.8 \pm 0.8 \mathrm{~kg}$ at slaughter. The animals were anesthetized (fluothane-nitrous oxide plus heparinized penthotal) and killed by intracardiac puncture. The cardiovascular system was washed with isotonic saline and the following organs were removed: liver, intestine, lung, heart, kidney, adrenals, aorta, perirenal adipose tissue, bone marrow, brain, spinal cord, ovaries, skin and muscle. Bone marrow was removed directly from several vertebrae. The skin was cut off the neck and the hair shaved off. The muscles were stripped from the rump and the fillet, and freed of connective tissue ; intestinal contents were discarded by washing. After homogenization, each organ was stored in alcohol and the heparinized blood was centrifuged $(2200 \mathrm{~g}$ at $4^{\circ} \mathrm{C}$ for $20 \mathrm{~min}$.) ; plasma and red cells were recovered.

Lipid was extracted in Kumagawa by alcohol 99. Free and esterified sterols were separated on silicic acid column (Chevallier and Mathé, 1964). After saponification, the sterols were precipited by digitonin and quantified by Lieberman-Burchard reaction. Sterol analysis was done by gas-liquid chromatography using a Varian Aerograph 1400 Model instrument equipped with a ionisation hydrogen flame detector. A $2 \mathrm{~mm} \times 1.5 \mathrm{~m}$ glass column, packed with 2 p. 100 QF $_{1}$ (fluoroalkyl silicone) on 100-120 mesh Varaport 30 (Varian Aerograph), was used isothermally at $200^{\circ}$. Nitrogen was the carrier at a flow of $30 \mathrm{ml} / \mathrm{min}$. Injector and detector temperatures were 250 and $260^{\circ}$, respectively. The internal standard $5 \alpha$-cholestane was selected because of its short retention time and complete resolution was obtained from the cholesterol peak. Sterols were identified by comparing their retention times with those of known standards previously performed by D'Hollander and Chevallier (1969). Figure 2 represents the order of GLC outflow.

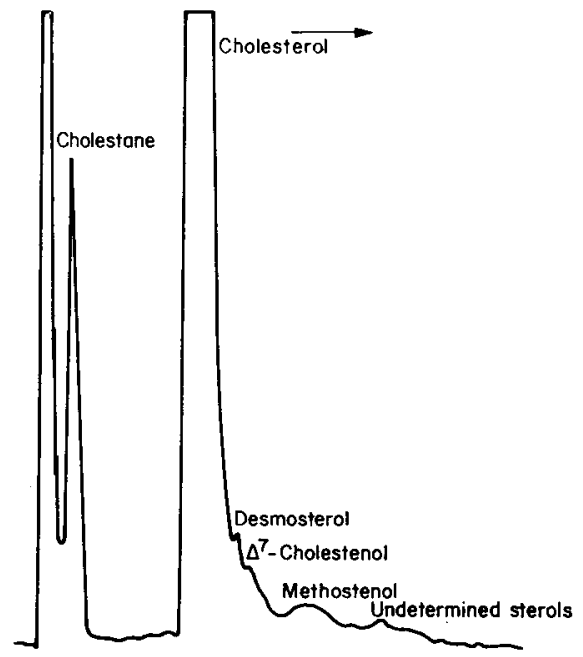

FIG. 2. - Gas liquid chromatogram of swine sterol organs (free and esterified form) after breaking steroldigitonin complex. Column conditions : Glass column was 2 p. $100 \mathrm{OF}_{1}$ (fluoroalkyl nitrogen as carrier gas at $30 \mathrm{ml} / \mathrm{min}$. 


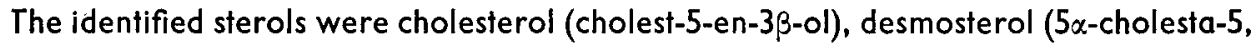

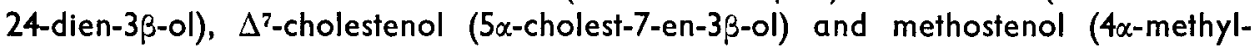
$5 \alpha$-cholest-7-en-3 $\beta$-ol). Traces of other sterols were detected. Because of their unknown nature, they were grouped as « undetermined sterols ». Sterols other than cholesterol were present in minute amounts. Since there was significant error in the determination of trace amounts, + is used to denote less than 1 p. 100 , while 1 to 2 p. 100 is designated by ++ .

\section{Results.}

Relative sterol proportions were only determined in the two swine killed after 3 weeks. Cholesterol represented 64.5 p. 100 of the free sterols in hair, 94 p. 100 in bone marrow and 98 p. 100 or more in all other organs (table 1). It was the only free sterol detected in the ten organs; liver, lung, heart, kidney, adipose tissue, spinal cord, brain, muscle, plasma and erythrocytes. As to other free sterols, hair contained 35.5 p. 100 of desmosterol and bone marrow 3 p. 100 of $\Delta^{7}$-cholestenol. Elsewhere, cholesterol was the only esterified sterol detected in ten organs: lung, heart, kidney, adrenals, adipose tissue, spinal cord, brain, ovaries, muscle and plasma. Once again, desmosterol concentration was high in hair (18.2 p. 100).

Large variations of free and esterified cholesterol concentrations were observed in certain organs (bone marrow, ovaries, adrenals, adipose tissue, hair, skin). These

\section{TABLE 1}

Mean percentages of cholesterol, desmosterol, $\Delta^{7}$-cholestenol, methostenol and undefermined sterols in the free $(F)$ and esterified $(E)$ fractions of certain organs of two adult female swine $(+:$ less than 1 p. $100 ;++: 1-2$ p. 100)

\begin{tabular}{|c|c|c|c|c|c|c|c|c|c|c|}
\hline \multirow[t]{2}{*}{ Sterol } & \multicolumn{2}{|c|}{ Cholesterol } & \multicolumn{2}{|c|}{ Desmosterol } & \multicolumn{2}{|c|}{$\Delta^{7}$-cholestenol } & \multicolumn{2}{|c|}{ Methostenol } & \multicolumn{2}{|c|}{$\begin{array}{l}\text { Undetermined } \\
\text { sterols }\end{array}$} \\
\hline & $\mathrm{F}$ & $E$ & $\mathbf{F}$ & $E$ & $F$ & $E$ & $F$ & E & $\mathbf{F}$ & $\mathbf{E}$ \\
\hline 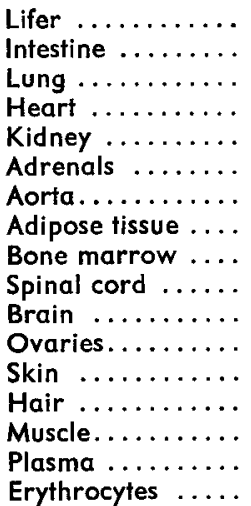 & $\begin{array}{r}100 \\
98 \\
100 \\
100 \\
100 \\
99 \\
98 \\
100 \\
94 \\
100 \\
100 \\
98 \\
98 \\
64 \\
100 \\
100 \\
100\end{array}$ & $\begin{array}{r}98 \\
98 \\
100 \\
100 \\
100 \\
100 \\
99 \\
100 \\
99 \\
100 \\
100 \\
100 \\
98 \\
82 \\
100 \\
100 \\
0\end{array}$ & 36 & 18 & $\begin{array}{r}+ \\
3\end{array}$ & $t^{-}$ & + & + & $\begin{array}{r}+ \\
3\end{array}$ & $\frac{++}{+t}$ \\
\hline
\end{tabular}


variations cannot, however, be correlated with the time of maintenance $(3,10,11$ and 32 weeks) on the semi-purified diet. Consequently, only the means of data and standard error (SEM) are reported (table 2). One exception concerned the plasma (table 3), where the concentrations of free and esterified cholesterol decreased slowly with time. The difference was significant (Student's $t$ test) between 3 and 32 weeks (0.01 $P<P<0.02)$.

The highest percentage of esterification was found in the plasma (approximately 76 p. 100); this value was not age-dependent (table 3 ). In the ovaries, adrenals and

\section{TABLE 2}

Mean concentration $(\mathrm{mg} / \mathrm{g})$ of free $(\mathrm{F})$ and esterified $(E)$ sterols $( \pm S E M)$ in 16 organs and tissues of 20 adult female swine

\begin{tabular}{|c|c|c|c|}
\hline & $\begin{array}{l}\text { Free } \\
\mathrm{mg} / \mathrm{g}\end{array}$ & $\begin{array}{c}\text { Esterified } \\
\mathrm{mg} / \mathrm{g}\end{array}$ & $\begin{array}{l}\frac{E}{E+F} 100 \\
\text { p. } 100\end{array}$ \\
\hline 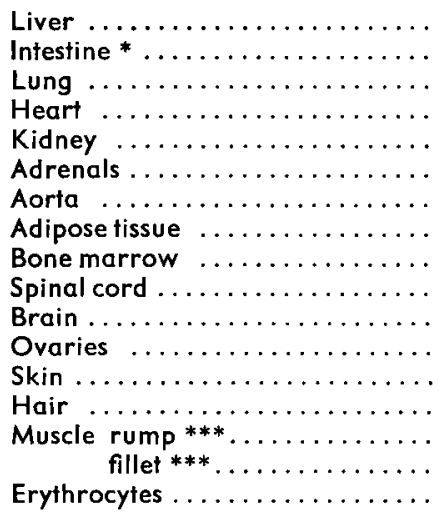 & $\begin{array}{l}2.14 \pm 0.34 \\
1.83 \pm 0.14 \\
3.27 \pm 0.34 \\
0.98 \pm 0.11 \\
3.12 \pm 0.37 \\
4.67 \pm 3.46 \\
1.08 \pm 0.14 \\
1.02 \pm 0.46 \\
0.97 \pm 0.35 \\
55.0 \pm 5.4 \\
24.2 \pm 3.2 \\
1.94 \pm 0.63 \\
0.76 \pm 0.20 \\
1.71 \pm 0.44 \\
0.48 \\
0.57 \\
1.36 \pm 0.01\end{array}$ & $\begin{array}{l}0.22 \pm 0.04 \\
0.07 \pm 0.01 \\
0.04 \pm 0.01 \\
0.03 \pm 0.01 \\
0.04 \pm 0.04 \\
0.64 \pm 0.34 \\
0.03 \pm 0.01 \\
0.05 \pm 0.03 \\
0.04 \pm 0.01 \\
0.03 \pm 0.01 * * \\
0.02 \pm 0.01 * * \\
0.56 \pm 0.39 \\
0.05 \pm 0.02 \\
0.15 \pm 0.11 \\
0.006 \\
0.008 \\
0\end{array}$ & $\begin{aligned} & 9.5 \pm 1.5 \\
& 3.5 \pm 0.6 \\
& 1.3 \pm 0.5 \\
& 2.8 \pm 1.0 \\
& 1.2 \pm 0.3 \\
& 15.9 \pm 9.8 \\
& 2.5 \pm 1.0 \\
& 5.1 \pm 2.9 \\
& 4.3 \pm 1.1 \\
& 0.06 \pm 0.01 \\
& 0.07 \pm 0.01 \\
& 21.9 \pm 9.0 \\
& 6.5 \pm 2.3 \\
& 6.8 \pm 3.6 \\
& 1.2 \\
& 1.2 \\
& 0\end{aligned}$ \\
\hline
\end{tabular}

* 12 swine.

** 6 swine.

*** 2 swine.

TABLE 3

Mean concentration $(\mathrm{mg} / \mathrm{ml})$ of free $(F)$ and esterified $(E)$ sterols $( \pm S E M)$ in the plasma of adult female swine killed after various times of maintenance on a semi-purified diet

\begin{tabular}{cccccc}
\hline $\begin{array}{c}\text { Age } \\
\text { (week) }\end{array}$ & $\begin{array}{c}\text { Time } \\
\text { mainfenance } \\
\text { (week) }\end{array}$ & $\begin{array}{c}\text { Number of } \\
\text { swine }\end{array}$ & $\begin{array}{c}\text { Free } \\
(\mathrm{mg} / \mathrm{g})\end{array}$ & $\begin{array}{c}\text { Esterified } \\
(\mathrm{mg} / \mathrm{g})\end{array}$ & $\frac{\mathrm{E}}{\mathrm{E}+\mathrm{F}}$ 100 \\
\hline 35 & 3 & 2 & $0.184 \pm 0.003$ & $0.631 \pm 0.042$ & 77.4 \\
42 & 10 & 14 & $0.154 \pm 0.005$ & $0.491 \pm 0.016$ & 76.1 \\
43 & 11 & 2 & $0.156 \pm 0.019$ & $0.519 \pm 0.068$ & 76.9 \\
64 & 32 & 2 & $0.136 \pm 0.005 a$ & $0.412 \pm 0.017 a$ & 75.2 \\
\hline
\end{tabular}

a $0.01 \leqslant \mathrm{P} \leqslant 0.02$ versus results of 3 weeks maintenance time. 
liver, the percentages ranged from 9.5 to $22 \mathrm{p} .100$ (table 2), and in another group of organs (adipose tissue, bone marrow, skin and hair) from 4.3 to 6.8 p. 100. In all other organs, this value was even lower. Esterified cholesterol was not detected in erythrocytes.

TABLE 4

\begin{abstract}
Mean weights $(\mathrm{g})$ of certain organs of six female swine and mean contents $(\mathrm{mg})$ of corresponding extracted sterols
\end{abstract}

\begin{tabular}{|c|c|c|}
\hline & $\begin{array}{l}\text { Organ weight } \\
(\mathrm{g})\end{array}$ & $\begin{array}{l}\text { Sterol content } \\
(\mathrm{mg})\end{array}$ \\
\hline 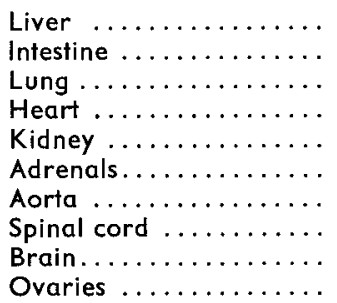 & $\begin{array}{r}1546 \\
1166 \\
935 \\
324 \\
127 \\
3.5 \\
25.2 \\
42.5 \\
104.5 \\
11.5\end{array}$ & $\begin{array}{r}3429 \\
2320 \\
2975 \\
351 \\
418 \\
24 \\
29 \\
2204 \\
2263 \\
34\end{array}$ \\
\hline
\end{tabular}

\title{
Discussion.
}

The mean concentration of free and esterified sterols in the organs of adulte female swine is fairly constantly independent of the duration the semi-purified dief was fed, except for the plasma where the concentration significantly decreased between experimental weeks 3 and 32 ; at that time, the swine were 35 and 64 weeks old (table 3). The total cholesterol concentration of two females maintained on the ground stock diet also decreased with age. This value was $0.787 \mathrm{mg} / \mathrm{ml}$ at 24 weeks and $0.667 \mathrm{mg} / \mathrm{ml}$ at 36 weeks ; the difference, however, is not statistically significant. Nevertheless, these observations suggest that the decrease observed in the experimental swine was due to the ageing of the animals. This decrease is not reported by McClellan et al. (1972) with miniature swine (Pitman-Moore stain). The discrepancy in the findings may be explained either by the nature of the two strains used, or by the particular diet dief fed to them. Let us add that in swine sex does not affect serum cholesterol levels (Rothschild and Chapman, 1976) as it does in humans (Schilling et al., 1964) and mature mice (Weibust, 1973).

Kim et al. (1974) measured the total cholesterol concentration in male swine of the Large White strain after seven weeks of feeding a hypercholesterolemic diet. The cholesterol concentrations they measured were generally higher than those detected in the present study in the blood, liver, lungs, kidneys, intestine and skin. Simultaneous administration of cholestyramine or clofibrate, however, lowered the concentrations in those organs, and they were then close to the data presented in table 2 . On the contrary, significant differences are observed in sterol distribution in various organs (table 4). For example, the sterol content in the lungs is twice as high in the current 
experiment as in that of Kim et al. Such comparisons only express the variations in relative organ weight between 2 groups of swine of different ages and submitted to different feeding conditions.

On the other hand, comparison of the present data with those obtained on rats (D'Hollander and Chevallier, 1969), shows strikingly similar sterol concentrations in all organs and tissues, except for the adrenals and bone marrow in which concentrations are 2 to 3 times greater in rats than in swine. Swine organs are poor in precursor sterols as compared to rat organs, particularly for esterified sterols. Moreover, the percentage of esterification in the majority of rat organs is 3 to 10 times greater for precursor sterols than for cholesterol. This is not observed in swine.

Reçu en avril 1978.

Accepté en juin 1978.

Acknowledgments. - We are most grateful to Dr P. A. Villiers for his technical assistance (bleeding and dissection of swine) and Mr F. Dacher for animal care.

Résumé. Des truies adultes ont été maintenues à poids constant $(70 \mathrm{~kg})$ par une restriction contrôlée de l'alimentation semi-synthétique qui leur est fournie. Les concentrations du cholestérol libre et estérifié déterminées dans 17 tissus ou organes sont indépendantes de la durée de l'expérience ( 3 à 32 semaines) à une exception près. Dans le plasma, on a noté une diminution significative de la cholestérolémie. Ces résultats sont discutés et comparés à ceux obtenus précédemment avec des animaux de même espèce ou avec des rats.

Les analyses par chromatographie en phase gazeuse ont montré que le cholestérol est le principal stérol des fractions libre et estérifiée des stérols. Le pourcentage correspondant atteint 98 p. 100 ou plus dans chaque organe ou tissu sauf dans les poils et la moelle osseuse (fraction libre seulement). Dans les poils, le desmostérol représente 35,5 p. 100 des stérols libres et 18,2 p. 100 des stérols estérifiés. Le $\Delta^{7}$-cholesténol et le méthosténol, autres précurseurs du cholestérol, ont été détectés en traces dans plusieurs organes. Le premier d'entre eux afteint 3 p. 100 des stérols libres de la moelle osseuse. Comparativement aux rats, les organes de la truie sont pauvres en stérols précurseurs du cholestérol.

\section{References}

CHEVALLIER F., MATHÉ D., 1964. Destinée du cholestérol des chylomicrons chez le rat. III. Mouvements de cholestérol-4-14 C entre les chylomicrons ef la lymphe ou le sérum in vivo. Bull. Soc. Chim. biol., 46, 509-527.

CMELIK S. H. W., LEY H., 1975. Distribution of cholesteryl esters and other lipids in subcellular fractions of the adrenal gland of the pig. Lipids, 10, 707-713.

D'HOLLANDER F., CHEVALLIER F., 1969. Estimation qualitative ef quantitative des stérols libres et estérifiés du rat in foto el de 23 de ses tissus ou organes. Biochim. biophys. Acta, 176, 146-162.

FAUSCH H. D., RICHMOND R., ANDERSON T. A., 1968. Infiuence of fasting on body composition and tissue cholesterol levels in swine. J. Anim. Sci., 27A, 1273-1275.

GRAY G. M., YARDLEY H. J., 1976. Lipid compositions of cells isolated from pig, human and rat epidermis, J. Lipid Res., 16, 434-440.

KIM D. N., LEE K. T., REINER J. M., THOMAS W. A., 1974. Restraint of cholesterol accumulation in tissue pools associated with diastic short-term lowering of serum cholesterol levels by clofibrate or cholestyramine in hypercholesterolemic swine. J. Lipid Res., 15, 326-331.

MCCLELLAN R. O., VOGT G. S., RAGAN H. A., 1972. Age-related changes in hematological an serum biochemical parameters in miniature swine, pp. 597-610. In BUSTAD L. K., McCLEELAN R. O., BUANS M. P., Swine in biomedical research, Wiley Interscience, New York. 
Nutrient requirements of swine, $1968 . \quad$ Nat. Acad. Sci. Publication 1599, 3-23.

REISER R., SORRELS M. F., WILLIAMS M. C., 1959. Influence of high levels of dietary fats and cholesterol on atherosclerosis and lipid distribution in swine. Circulation Res., 7, 833-846.

ROBINSON O. W., 1976. Growth patterns in swine. J. Anim. Sci., 42, 1024-1035.

ROTHSCHILD M. F., CHAPMAN A. B., 1976. Factors influencing serum cholesterol levels in swine. J. Hered., 67, 47-48.

SCOTT A. F., MORRISON E. S., 1968. Diefary induced atherosclerosis in miniature swine. III. Lipid values : cholesterol, triglyceride and phospholipid, and esterified fatty acid values in serum and in aortic intima-media tissue. Exper. molec. Path., 8, 263-301.

SCHILLING F. J., CHRISTAKIS G. J., BENNETT N. J., COYLE J. T., 1964. Studies of serum cholesterol in-4, 244 men and women : an epidemological and pathogenetic interpretation. Am. J. public. Health, 54, 461-476.

STOKKE K. T., 1974. Cholesteryl ester metabolism in liver and blood plasma of various animal species. Atherosclerosis, 19, 393-406.

WEIBUST R. S., 1973. Inheritance of plasma cholesterol levels in mice. Genetics, 73, 303-312. 